\title{
Detecting hydro-climatic change using spatiotemporal analysis of rainfall time series in the Cobres River basin, Portugal
}

\author{
CELSO AUGUSTO GUIMARÃES SANTOS ${ }^{\mathbf{1}}$, RICHARDE MARQUES DA SILVA ${ }^{\mathbf{1}}$, \\ MADALENA MOREIRA ${ }^{2}$, JOÃO CORTE-REAL ${ }^{2} \&$ LÍGIA RABAY MANGUEIRA ${ }^{\mathbf{1}}$ \\ 1 Federal University of Paraiba, Department of Civil and Environmental Engineering, 58051-900 João Pessoa, PB, \\ Brazil \\ celso@ct.ufpb.br \\ 2 Institute of Mediterranean Agrarian and Environmental Sciences (ICAAM), Group Water, Soil and Climate, \\ University of Evora, Núcleo da Mitra, 7002-774 Evora, Portugal
}

\section{INTRODUCTION}

The knowledge of climatic behaviour, especially in semi-arid regions, is required to optimize the management of water resources. In this study, the climate variability is directly related to water resources that are of a high socio-economic and environmental significance. To optimize the hydraulic constructions, one needs to know the climatic behaviour of the region concerned, the role of which is very important to water resources management in the short, medium and long term.

A comprehensive understanding of river flow and its distribution in time and space is essential for water resources management in the arid and or semi-arid regions. In recent years, various studies have been done to detect possible climate trends and changes across the world, analysing changes in temperature and precipitation only (Yang et al. 2014).

The river flow regime in Portugal is highly seasonal, being clearly Mediterranean with a rainy season in the autumn and winter (November to March) and an extremely dry summer. The river flows are also very irregular, with severe droughts contrasting with surprisingly high flood discharges. The main objective of this study is to obtain a better understanding of the spatial and temporal variability and trends of river flow in the Cobres River basin, southern Portugal, using statistical tools.

\section{MATERIAL AND METHODS}

Datasets of daily rainfall recorded at two raingauges were analysed (Entradas and Monte da Ponte). Daily data from two river flow stations for the period 1960-1989, obtained from the Sistema Nacional de Informação de Recursos Hidricos, available at http://www.snirh.pt, were used to study the seasonality and trends on an annual basis. In this study, the trends of river flow in the basin were analysed by the Mann-Kendall $\left(Z_{s}\right)$ (Kendall 1975) and the Sen's slope $\left(Q_{m e d}\right)$ (Sen $1968)$ tests. A detailed statistical analysis applied to the river flow time series of all gauges indicates that runoff is highly temporally variable and there is a decrease in the annual rainfall amount for the period studied (1960-1989).

\section{RESULTS AND DISCUSSION}

Table 1 shows descriptive statistics of the annual river flow series at the study stations. The results indicated that Monte da Ponte station, with an average annual river discharge of $0.94 \mathrm{~m}^{3} \mathrm{~s}^{-1}$, had the highest annual water yields. In contrast, Entradas station had the lowest annual water yields. Moreover, the monthly river discharge time series of Entradas station with coefficient of variations (CV) of $73.23 \%$ showed the highest temporal variability. The lowest CV of $59.37 \%$ was found at Monte da Ponte station. The results of CV showed high annual variability of the river discharge at the stations over the study period.

The Mann-Kendall test and Sen's slope estimator were applied to the time-series for the two river flow gauges. None of the stations showed significant serial correlation. Time series with significant serial correlation at the significance level of 0.05 were subjected to pre-whitening 
Table 1 Descriptive statistics of the annual river discharge series at the study stations.

\begin{tabular}{|c|c|c|c|c|c|c|c|c|}
\hline \multirow[t]{2}{*}{ Stations } & Mean & SD & $\mathrm{DM}$ & Max & Min & \multirow{2}{*}{$\begin{array}{l}\text { CV } \\
(\%) \\
\end{array}$} & \multirow[t]{2}{*}{$Z_{S}$} & \multirow[t]{2}{*}{$Q_{m e d}$} \\
\hline & \multicolumn{5}{|c|}{$\left(\mathrm{m}^{3} \mathrm{~s}^{-1}\right)$} & & & \\
\hline Pulo do Lobo & 0.94 & 0.71 & 0.62 & 2.82 & 0.01 & 0.51 & -1.07 & -0.0002 \\
\hline Monte da Ponte & 0.10 & 0.06 & 0.05 & 0.21 & 0.00 & 0.00 & -0.09 & -0.008 \\
\hline
\end{tabular}

SD: standard deviation, DM: mean deviation, CV: coefficient of variation.

procedure before applying the trend tests. The results of the trend tests on the annual river discharge series are: (a) Pulo do Lobo $=-1.07$, and (b) Monte da Ponte $=-0.09$. Trends are considered statistically significant at the 0.05 level when identified by the two statistical methods, viz: Mann-Kendall and Sen. The results indicate that Monte da Ponte and Pulo do Lobo stations were characterized with a negative trend, suggesting a possible future water resources scarcity for this point. Annual river discharge variation at Pulo do Lobo and Monte da Ponte stations for the period 1960-1989 is plotted in Fig. 1(a)-(b), which shows the decreasing tendency of annual river discharge at the Monte da Ponte $\left(Z_{S}=-0.09\right)$ station and at the Pulo do Lobo station $\left(Z_{S}=-1.07\right)$. As shown, annual mean river flow at Monte da Ponte station declined by $18.9 \%$ from $0.15 \mathrm{~m}^{3} \mathrm{~s}^{-1}$ in 1958 to $0.12 \mathrm{~m}^{3} \mathrm{~s}^{-1}$ in 1989 . The elevation of the basin and its relief around are by far the most important geological control upon rainfall and, consequently, of river flow within the region.

(a)

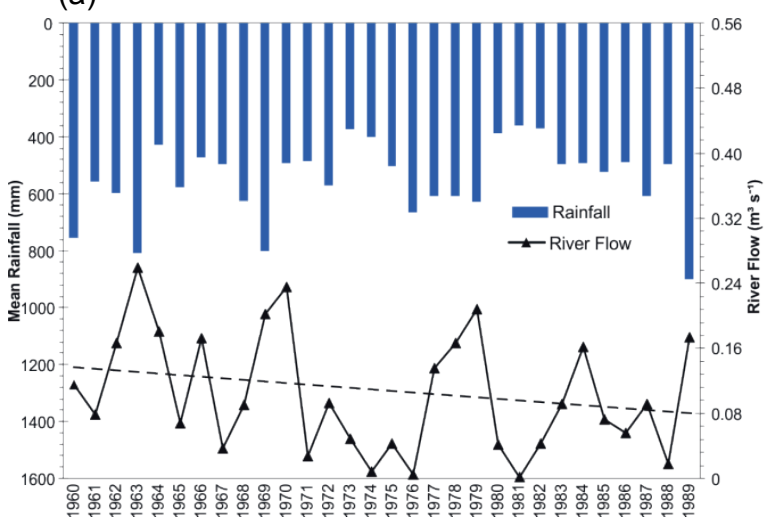

(b)

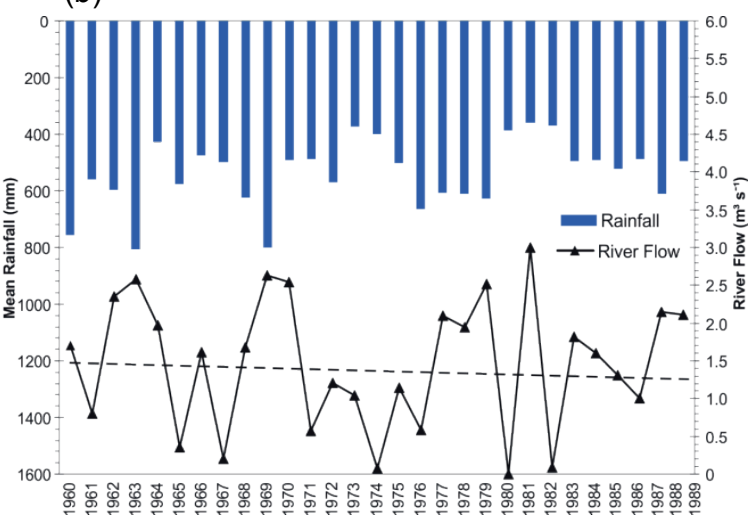

Fig. 1 Annual average river flow between 1960 and 1989 for: (a) Pulo do Lobo and (b) Monte da Ponte.

The results of these trend analyses clearly indicate that although there have been persistent oscillations from normal rainfall and river flow within the basin, there has been no consistently negative long-term temporal trends. The results of similar Mann-Kendall tests also indicate that there is a statistically significant trend with respect to successive 39-year sets of rainfall variance and time within the study area. There has been ample variation on the mean values in the river flow. In short, these results indicate that annual mean river flow in the Cobres River basin have become more variable between 1960 and 1989. Both rainfall and river flow vary greatly from year to year within the basin and it is not uncommon for rainfall to be well above average one year followed by a year of well below average rainfall and river flow.

\section{REFERENCES}

Kendall, M.G. (1975) Rank Correlation Methods. Griffin, London, UK.

Sen, P.K. (1968) Estimates of the regression coefficient based on Kendall's tau. Journal of the American Statistical Association 63, 1379-1389.

Yang, K., et al. (2014) Recent climate changes over the Tibetan Plateau and their impacts on energy and water cycle: A review. Global and Planetary Change 112(1), 79-91. 